\title{
Coprostanol levels and organic enrichment in sediments of the Bilbao estuary (north of Spain)
}

\author{
José Ignacio SAIZ-SALINAS ${ }^{\text {a }}$, José Antonio GONZÁLEZ-OREJA ${ }^{\text {b }}$ \\ Department of Zoology \& ACD, University of the Basque Country, P.O. Box 644, E-48080-Bilbao, Spain \\ ${ }^{a}$ E-mail: ggpsasaj@lg.chu.cs \\ ${ }^{b}$ E-mail: ggbgoorj@lg.ehu.es
}

(Revised 14/11/97, accepted 21/11/97)

\begin{abstract}
An assessment was made of the distribution of the faecal sterol coprostanol (COP) in sediments in the Bilbao estuary. Concentrations of COP ranged from 135.15 to $10.77 \mu \mathrm{g} \mathrm{g}^{-1}$ dry weight, from the inner to the open estuary, with a mean value of $51.43 \mu \mathrm{g} \mathrm{g}^{-1}$; the highest concentrations were found near the mouths of several tributaries flowing into the estuary. Comparisons with other published values indicate that sediments from the Bilbao estuary are affected by sewage pollution in a similar degree to that reported for other estuaries in the world. Organic enrichment and anaerobic sediment conditions prevail in three-fourths of its watercourse bed. Since the spatial distribution of several organic sedimentary parameiers could be clearly correlated with COP levels, we can conclude the existence of major pollution by the addition of untreated sewage, coming from mainly domestic sources. The implementation of a sewerage treatment plan by the local water authority needs the monitoring of reliable sewage traccrs, such as faccal sterols, to assess the cffectiveness of the plan in reducing the effects of pollution. () Elsevier, Paris
\end{abstract}

\section{Bilbao estuary / coprostanol / sediment / organic enrichment / sewage pollution}

Résumé - Teneurs en coprostanol et enrichissement organique dans les sédiments de l'estuaire de Bilbao (nord de l'Espagne). La répartition du stérol fécal coprostanol (COP) a été évaluée dans les sédiments de l'estuaire de Bilbao. Les concentrations en COP décroissent de 135,15 à $10,77 \mu \mathrm{g} \mathrm{g}^{-1}$ de poids $\mathrm{sec}$, de l'intérieur vers le large, avec une valeur moyenne de $51,43 \mu \mathrm{g} \mathrm{g}^{-1}$, les valeurs les plus élevées étant trouvées à l'embouchure de plusieurs affluents. La comparaison avec d'autres résultats publiés indique que les sédiments de l'estuaire de Bilbao sont atteints par la pollution des égoûts à un niveau comparable à celui d'autres estuaires dans le monde. L'enrichissement organique et les conditions anaérobiques règnent sur les $3 / 4$ du lit du cours d'eau. Comme la répartition spatiale de plusieurs paramètres de la sédimentation organique est corrélée aux niveaux de COP, on peut conclure à une pollution majeure par des rejets non traités, provenant principalement de sources domestiques. La réalisation d'un plan de traitement des rejets par l' "Autorité de l'Eau" locale exige le suivi de traceurs pertinents, comme les stérols fécaux, pour apprécier l'efficacité du plan sur la réduction de la pollution. (C) Elsevier, Paris

estuaire de Bilbao / coprostanol / sédiment / enrichissement organique / pollution

\section{INTRODUCTION}

Recently, there has been great interest in the use of biological and chemical markers to quantify urban and sewage-derived pollution in estuarine and marine environments and to control the sanitary quality of waters. One of these chemical markers, coprostanol (5ß-
cholestan-3B-ol or COP), which is produced in the intestines of man and higher vertebrates by the microbial reduction of cholesterol [25], offers a wide range of advantages over the classical microbiological techniques that use several classes of bacteria, particularly those of the coliform group, to trace faecal-derived inputs in the environment [14, 24, 25].

\footnotetext{
* Correspondence and repritns
} 
The physical environment of the Bilbao estuary has been extremely modified since the end of the nineteenth century mainly through the construction of docks, canalisation, and harbour dredgings to improve its navigation. Although a sewerage plan is now underway, large amounts of untreated domestic sewage from about one million people together with wastes from industries and harbour activities are continually discharged daily into a 14-km long estuary with a limited freshwater inflow of $25 \mathrm{~m}^{3} \cdot \mathrm{s}^{-1}$. The biological effects of these man-induced activities lead to a severe oxygen deficiency in the waters of the middle and upper reaches of the estuary, affecting aerobic life in subtidal sediments to such an extent that macro-infauna is absent in almost three-fourths of its watercourse bed [19].

The object of this study is to use the faecal sterol COP as a sewage tracer for evaluating contamination of the sediments of the Bilbao estuary by sewage addition. In the future, these results could provide background data in the assessment of the effectiveness of the previously mentioned sewerage plan in reducing pollution effects.

\section{MATERIALS AND METHODS}

\subsection{Study area}

A total of eight stations were selected along a longitudinal gradient of salinity dilution from the mouth of the estuary (St. 2: Benedicta Dock) to the upper reaches, where the city of Bilbao lies (St. 9: La Salve); a 'control' or reference station (RS) was established in a nearby and relatively unpolluted estuary (St. 1: Plentzia; figure 1). A single tide level was sampled at each station (approx. $1 \mathrm{~m}$ above Spanish Ordnance Datum).

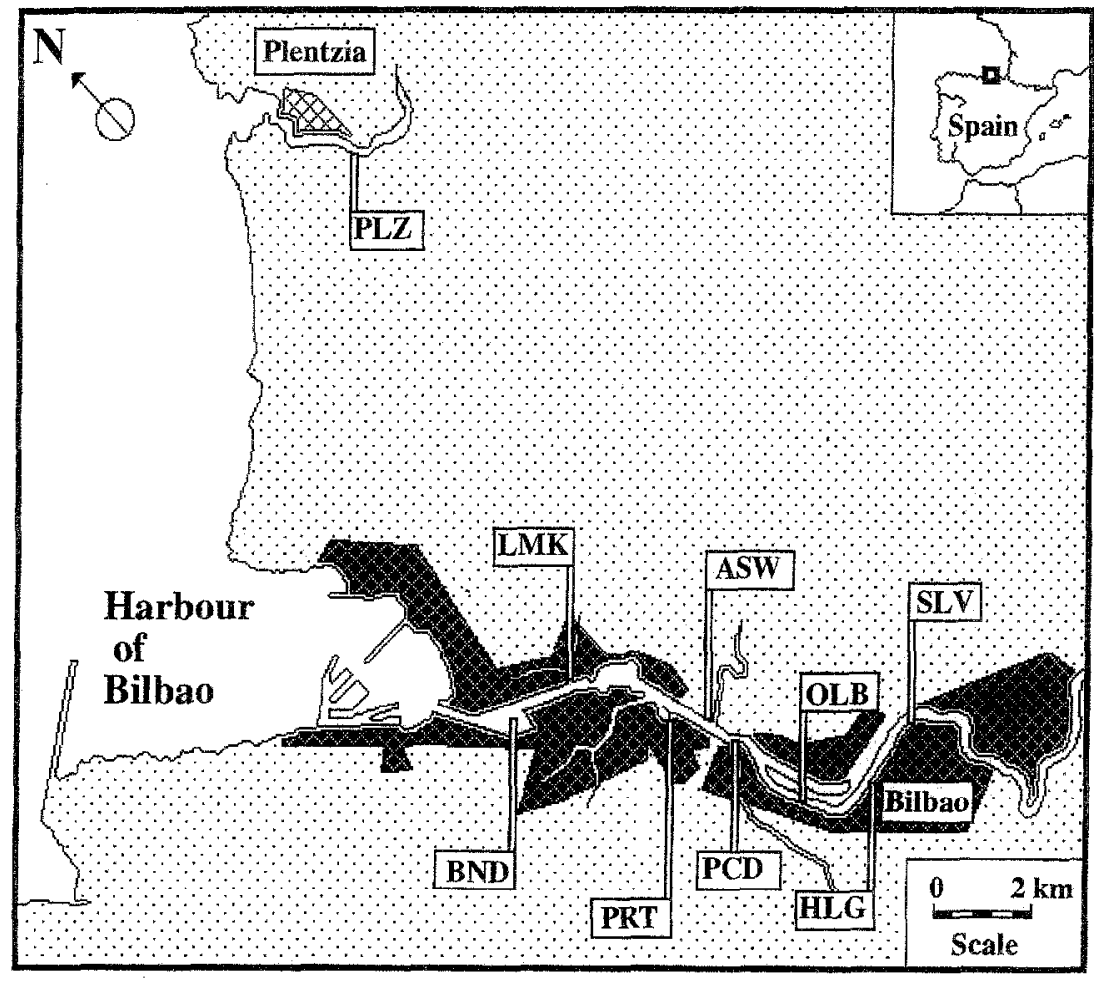

Figure 1. Diagram of the Bilbao and Plentzia estuaries, with the location of the sampling sites used in this study. The populated zones are shaded. At the time of the sampling, the real population living in the Bilbao estuary was approximately 950000 habitants, and the served population was about 375000 habitants [4]. The insef shows the position of the investigated area in Spain.

Station acronyms and names: PLZ: Plentzia ('reference site'); BND: Benedicta Dock; LMK: Lamiako; PRT: Portu Dock; ASW: Asúa; PCD: El Puntal; OLB: Olabeaga; HLG: Helguera; SLV: La Salve. The HLG site, Helguera, was the foremost sewage discharge source into the estuary at the time of the sampling. 


\subsection{Sample collection and analysis}

Redox potential $(\mathrm{Eh})$ profiles in sediment columns were obtained in situ by using ORP (Hanna HI $3130 \mathrm{~B}$ or HI 3131B) electrodes coupled to a Hanna model HI $9025 \mathrm{c}$ $\mathrm{mV}$-meter. Readings of Eh were taken after an arbitrary $60 \mathrm{~s}$ period [15]. A standard redox solution (Hanna HI 7020) was used as reference in the checking routine. The upper $10 \mathrm{~cm}$ of sediment columns were centrifuged for 10 min at $4{ }^{\circ} \mathrm{C}$, and the interstitial water (IW) collected for salinity measures with a Hanna FC 300 sodium ion electrode connected to a Hanna HI 9190 sodium chloride analyser. A reference sodium solution Hanna HI 7081 was used to evaluate the measuring accuracy. During low tides, surficial sediment samples (top $0.5 \mathrm{~cm}$ layer) from an area of approximately $1 \mathrm{~m}^{2}$ were scraped off with a polyethylene spatula and transferred to labelled polyethylene vials. Once in the laboratory, sediment samples were frozen until analysis $\left(-25^{\circ} \mathrm{C}\right)$, focusing on the surficial layer due to both its relation to more recent material inputs and its higher biological signification. Particle size distribution was performed by standard sieve and pipette (settling rate) methods of a sediment column of $10 \mathrm{~cm}$ deep, following the technique recommended by Buchanan [2]. Organic content (loss-on-ignition or LOI and reported as ash-free dry weight) of surficial sediments was estimated by ashing at $520^{\circ} \mathrm{C}$ for $6 \mathrm{~h}$ and reweighing [12]. Analysis of total and organic carbon and nitrogen content in the surficial sediment were determined with a Perkin-Elmer model $240 \mathrm{CHN}$-analyser calibrated with acetanilide, utilising the difference on ignition (DOI) method proposed by Kristensen and Andersen [9].

\subsection{Coprostanol measures}

The faecal sterol COP was analysed after the EEC method no. 2568/91 for sterols. Weighed samples of dry sediments were Soxhlet extracted for $24 \mathrm{~h}$ with a $2 / 1$ (v/v) mixture of dichloromethane-methanol as solvent, and then the extract was saponified by adding $50 \mathrm{~mL}$ of $2 \mathrm{~N} \mathrm{KOH}$ in ethanol. Unsaponified fractions were dried over anhydrous sodium sulphate and evaporated under vacuum to approximately $2 \mathrm{~mL}$. An internal standard (stigmasterol, $1000 \mu \mathrm{g} \mathrm{g}^{-1}$ ) was added to all extracts prior to chromatography analysis. Extracts were applied to thin layer chromatography plates (silica gel, activated at $100^{\circ} \mathrm{C}$ for $1 \mathrm{~h}$; hexane-ethyl acetate $85 / 15(\mathrm{v} / \mathrm{v})$ as mobile phase). 2,7-Dichlorofluorescein was sprayed over the plate, and the sterol fraction was removed after visualisation with ultraviolet light and eluted with chloroform. Derivatisation into trimethylsilyl (TMS) ethers was prior to gas chromatography analysis. Silylation reactive $(1 \mathrm{~mL})$ was a mixture of $1: 10^{-5}: 3(\mathrm{v} / \mathrm{v} / \mathrm{v})$ of $\mathrm{N}, \mathrm{O}$-bis-(trimethylsilyl)-acetamide:trimethylchlrosilane: pyridine, $15 \mathrm{~min}$ being the reaction time.

\subsection{Gas chromatography}

The TMS-sterol fraction thus extracted was analysed on a Hewlett-Packard Model 5890 Series II. A $30 \mathrm{~m} \times 0.25$ mm i.d., $0.25 \mu \mathrm{m}$ film thickness, fused silica capillary column coated with poly $(5 \%$-diphenyl- $95 \%$-dimethylsiloxane) was used for analysis. A three-ramp temperature program was employed. Helium was the carrier gas, and the eluate was detected with a flame ionisation detector (FID). Coprostanol was identified by comparing relative retention times to previously analysed standards, and quantified by establishing the relative response of the FID for the standard added to each samples prior to thin layer chromatography analysis of the sample COP.

\subsection{Data analysis}

Statistical analysis and data transformations were conducted using SPSS for Macintosh. Data sets were analysed for normalily using the Kolmogorov-Smirnov test. If this analysis failed to meet the assumptions for parametric statistics, arcsine transformation was applied to the data, and the transformed data set was then re-evaluated for normality. Correlation analysis (Pearson's ProductMoment Correlation) was used to test for the strength and direction of associations between all the variables. Statistical significance was reported at $P<0.05$ [27].

\section{RESULTS}

IW salinities showed a longitudinal gradient that increased toward the mouth from the upper reaches of the estuary. Salinity was $10.9 \mathrm{~g} \mathrm{~L}^{-1}$ at upstream sites but increased progressively downstream to a maximum of $22.2 \mathrm{~g} \mathrm{~L}^{-1}$ close to the mouth. No longitudinal patterns were apparent for redox potential, particle size and organic content of depositional sediments, although stations in the middle reaches of the estuary had usually finer particle sizes and higher organic content. Sediments from the Bilbao estuary were anaerobic. Redox potentials 
at the sediment surface ranged from -64 to $-385 \mathrm{mV}$ and averaged $-265 \mathrm{mV}$. Sediment parameters showed no longitudinal trends, with sedimentary organic matter content dropping from 57.2 to $6.6 \%$, whereas the organic carbon ranged from 2.03 to $15.97 \%$ and total nitrogen varied from 0.2 to $0.86 \%$ on a dry weight basis. Measures of these sediment parameters at the RS were lower than the Bilbao estuary averages, although within the ranges found for this polluted estuary.

Coprostanol concentrations in surficial sediments from the Bilbao estuary ranged between 10.77 and $135.15 \mu \mathrm{g} \mathrm{g}^{-1}$ of dry sediment $(\bar{x}=51.43$; standard deviation $=45.56$ ), and were generally similar throughout the study area, except at the Helguera site, which was located close to the major sewage outfall in the estuary (figure l), and the Portu Dock. The RS exhibited a concentration of COP of $2.24 \mu \mathrm{g} \mathrm{g}^{-1}$ of dry sediment (table $I$ ).

Coprostanol values showed highly significant correlations $(P<0.01)$ with four organic content parameters of the sediment: surficial $(r=0.802)$ and total organic matter $(r=0.810)$, organic carbon $(r=0.876)$ and total nitrogen $(r=0.844)$.

\section{DISCUSSION}

Theoretically, unpolluted sediments do not contain COP [6] and certainly contain levels below the limit of detection of the technique [13]. There is no consensus, however, on whether COP clearly indicates sewage-derived pollution.
On the one hand, several researchers concluded that quantitation of COP provides, per se, a clear measure of sewage contribution to marine environments [13]. Indeed, Pierce and Brown [16] stated that the extent to which COP is distributed through an estuary provides an indication on the distribution of other sewage-derived pollutants [21]. On the other hand, other researchers needed more information about environmental stability and source specificity for its general acceptance as a sewage indicator, since COP occurrence in coastal areas cannot be unambiguously attributed to urban sewage pollution $\lceil 3,5,17\rceil$.

Although COP has been used by numerous researchers to evaluate this pollution, no specific level has been legislated defining excessive contamination [26]. Nichols and Leeming [13] stated that sediments considered to be grossly contaminated with sewage contained $9 \mu \mathrm{g}$ COP per gram sediment; however, there is great heterogeneity among all COP concentration values previously reported, ranging within several orders of magnitude. Some values for sediment concentration of COP, registered in both open and closed systems, are those of Hatcher and McGillivary [6]: 56-5 $200 \mathrm{ng} \mathrm{g}^{-1}$ in the New York Bight; Brown and Wade [1]: 19-454 $\mathrm{ng} \mathrm{g}^{-1}$ (mean 142) in the Chesapeake Bay; Grimalt et al. [5]: $0.41-3.5 \mu \mathrm{g} \mathrm{g}^{-1}$ in several cities mainly from the Spanish Mediterranean seashore; Venkatesan and Kaplan [23]: 1.1-5.1 $\mu \mathrm{g} \mathrm{g}^{-1}$ in Santa Monica Basin; Sherwin et al. [20]: 0.2-41 $\mu \mathrm{g} \mathrm{g}^{-1}$ in Venice; and Jeng and Han [8]: 0.58-230 $\mu \mathrm{g} \mathrm{g}^{-1}$ (mean 20.8) in Kaohsiung Harbour and the Tan-Shui estuary. The sediments of the Bilbao estuary are located in the middle of this scale, the mean value $\left(51.43 \mu \mathrm{g} \mathrm{g}^{-1}\right)$ being

Table I. Coprostanol concentrations, redox potential at the surface, salinity (interstitial water) values, organic matter content, and particle size fractions in sediments from all the stations considered in this study.

\begin{tabular}{|c|c|c|c|c|c|c|c|c|c|c|c|c|}
\hline Station name & $\begin{array}{c}\text { Coprostanol } \\
\left(\mu \mathrm{g} \cdot \mathrm{g}^{-1}\right)\end{array}$ & $\begin{array}{l}\text { Redox } \\
(\mathbf{m} \cdot V)\end{array}$ & $\begin{array}{l}\text { Salinity } \\
\left(\mathrm{g} \cdot \mathrm{L}^{-1}\right)\end{array}$ & \multicolumn{7}{|c|}{ Organic matter content } & \multicolumn{2}{|c|}{ Particle size } \\
\hline PLZ: Plentzia & 2.24 & 168 & 22.2 & 7.3 & 3.9 & 2.79 & 2.27 & 0.23 & 0.2 & 9.7 & 8.29 & 78.31 \\
\hline BND: Benedicta Dock & 20.98 & -300 & 20 & 14.2 & 7.5 & 7.16 & 5.52 & 0.37 & 0.06 & 11.2 & 10.4 & 77.1 \\
\hline LMK: Lamiako & 37.35 & -283.5 & 17 & 7.2 & 5.2 & 2.29 & 2.03 & 0.14 & 0.12 & 15 & 40.3 & 27 \\
\hline ASW: Asúa & 58.88 & -160 & 15.2 & 9.2 & 7.7 & 5.09 & 4.9 & 0.44 & 0.43 & 9.9 & 7.9 & 78.6 \\
\hline PCD: El Puntal & 10.77 & -64 & 17.5 & 6.6 & 11.1 & 4.04 & 2.76 & 0.25 & 0.24 & 10 & 23.3 & 52.1 \\
\hline OLB: Olabeaga & 11.48 & -335.3 & 10.9 & 14.7 & 5.5 & 6.87 & 5.62 & 0.43 & 0.43 & 11.2 & 22.3 & 77.6 \\
\hline HLG: Helguera & 135.15 & -285 & 12.2 & 57.2 & 16.2 & 19.98 & 15.97 & 0.86 & 0.8 & 17.1 & 26.8 & 58.3 \\
\hline SLV: La Salve & 24.71 & -340 & 17.4 & 8.5 & 2.4 & 3.64 & 3.19 & 0.2 & 0.17 & 15.8 & 26.5 & 49.6 \\
\hline
\end{tabular}

SOM: surficial organic matter; TOM: total organic matter; TC: total carbon; OC: organic carbon; TN: total nitrogen; ON: organic nitrogen; $\mathrm{C} / \mathrm{N}$ : carbon to nitrogen ratio (molar fraction). Units are indicated in parentheses. 
certainly higher than that of the reference by Nichols and Leeming [13]. Is it a clear indication of urban pollution?

Several researchers have demonstrated a positive correlation between COP concentrations and organic carbon in sediments $[1,6,20,23,26]$. Our results agree with this correlation. Applying the criteria developed for classifying sediments according to their content in organic matter [7], the more degraded zones in the Bilbao estuary are the upstream sites, i.e. Helguera, La Salve, and also the area around the Portu Dock, with organic matter contents over $12 \%$. Furthermore, the carbon/nitrogen $(\mathrm{C} / \mathrm{N})$ ratio provides a way of knowing the origin of this organic matter. Thus, a low $\mathrm{C} / \mathrm{N}$ ratio reflects particulates derived from a predominantly marine system, while a high $\mathrm{C} / \mathrm{N}$ ratio generally reflects terrestrial inputs $[11]$, i.e. a $\mathrm{C} / \mathrm{N}$ $>12$ identifies a terrestrial origin, while a $\mathrm{C} / \mathrm{N}$ between 6 and 9 generally detects marine origin [22]. Values obtained in this study ranged from 9.7 to $17.1,12.3$ being the mean value ( 2.83 the standard deviation), which is a clear indication of a terrestrial origin. Waste waters enhance both carbon and nitrogen inputs into the sediment. However, while a fraction of carbon is easily degraded via bacterial metabolism, other fractions remain in the systcm as refractarial carbon, which in turn enhance the $\mathrm{C} / \mathrm{N}$ ratio. Several tributaries flow into the Bilbao estuary (Gobelas at the Lamiako site, Galindo close to the Portu Dock, and Helguera), where the $\mathrm{C} / \mathrm{N}$ ratios are the highest. The same is true for the Portu Dock and La Salve, tracing important, presumably sewagederived organic matter inputs in the estuary.

Organic enrichment and anaerobic sediment conditions appear to be the clominant anthropogenic influences in the Bilbao estuary. Sediments are completely anoxic up to the water interface, with redox potential values as low as $-498 \mathrm{mV}$ (at $10 \mathrm{~cm}$ depth [19]). At these low redox values, the organic matter undergoes breakdown by anaerobic processes, with liberation of noxious gas bubbles at the air/water interface, a circumstance which prevails in many parts of the estuary during low tides. A sewerage scheme involving a network of interceptor and collector sewers with major wastewater treatment plants (WWTP) is now under construction. A progressive improvement of the estuarine water quality in several stages is expected [4]. The usefulness of COP as an indicator of treatment plant efficiency was proposed by Le Blanc et al. [10] and Quéméneur and Marty [18], since it is degraded under conditions of aerobic digestion during the secondary WWTPs. Thus, the quantification of COP and related organic chemical parameters in sediments, as they have been used here, are especially valuable in helping to assess the efficiency of the scwerage plan promoted by the local water authority in the forthcoming years.

\section{Acknowledgements}

This work was supported by funds from the Basque government contract no. A040/94. Concentrations of coprostanol were determined by the AZTI Laboratory of Biochemistry (Sukarrieta, Spain). José Antonio GonzálezOreja received a postgraduate grant from the Basque government (B.O.P.V., 28 February 1995). An anonymous referee greatly improved the original manuscript. The authors also thank Mr. David Hallett for kindly reviewing the English version of the text.

\section{REFERENCES}

[1] Brown R.C., Wade T.L., Sedimentary coprostanol and hydrocarbon distribution adjacent to a sewage outfall, Water Res. 18 (5) (1984) 621-632.

[2] Buchanan J.B., Sediment analysis, in: Holme N.A., McIntyre A.D. (Eds.), Methods for the Study of Marine Benthos, 2nd edition, Oxford, Blackwell Scientific Publ., 1984, pp. 41-65.

[3] Chalaux N., Takada H., Bayona J.M., Molecular markers in Tokyo Bay sediments: sources and distribution, Mar. Environ. Res. 40 (1) (1995) 77-92.

[4] Consorcio de Aguas del Gran Bilbao Agiria 95 Memoria, Consorcio de Aguas del Gran Bilbao, Bilbao (1996) 135 p.
[5] Grimalt J.O., Fernández P., Bayona J.M., Albaigés J., Assessment of fecal sterols and ketones as indicators of urban sewage inputs to coastal waters, Environ. Sci. Technol. 24 (3) (1990) $357-363$.

[6] Hatcher P.G., McGillivary P.A., Sewage contamination in the New York Bight. Coprostanol as an indicator, Environ. Sci. Technol. 13 (10) (1979) 1225-1229.

[7] Hily Ch., Variabilité de la macrofaune benthique dans les milieux hyper-trophiques de la Rade de Brest, tome 1, thèse, Univ. de Bretagne Occidentale, Brest, 1984, 359 p. 
[8] Jeng W.-L., Han B.-C., Sedimentary coprostanol in Kaohsiung Harbour and the Tan-Shui Estuary, Taiwan, Mar. Pollut. Bull. 28 (8) (1994) 494-499.

[9] Kristensen E., Andersen F.Ø., Determination of organic carbon in marine sediments: a comparison of two $\mathrm{CHN}$-analyzer methods, J. Exp. Mar. Bíol. Ecol. 109 (1987) 15-23.

[10] Le Blanc L.A., Latimer J.S., Ellis J.T., Quinn J.G., The geochemistry of coprostanol in watcrs and surface scdiments from Narragansett Bay, Estuar. Coast. Shelf S. 34 (1992) 439-458.

[11] Lccming R., Nichols P.D., An integrated scheme to analyse naturally occurring and pollutant organic constituents in urban sewage, in: Miskiewicz A.G. (Ed.), Proceedings of a Bioaccumulation Workshop: Assessment of the Distribution, Impacts and Bioaccumulation of Contaminants in Aquatic Environments, Water Board and Australian Marinc Scicnces Association Inc., Sydney, 1992, pp. 153-161.

[12] Miron G., Kristensen E., Factors influencing the distribution of nereid polychaetes: the sulfide aspect, Mar. Ecol. Prog. Ser. 93 (1993) 143-153.

[13] Nichols P.D., Leeming R., Tracing sewage in the marine environment. Chemistry in Australia, July 1991, (1991) 274-276.

[14] Nichols P.D., Leeming R., Rayner M.S., Latham V., Ashbolt N.J., Turner C., Comparison of the abundance of the fecal sterol coprostanol and fecal bacterial groups in inner-shelf waters and sediments near Sydney, Australia, J. Chromatography 643 (1993) 189-195.

[15] Pearson T.H., Stanley S.O., Comparative measurement of the redox potential of marine sediments as a rapid means of asses. sing the effect of organic pollution, Mar. Biol. 53 (1979) 371 379 .

[16] Pierce R.H., Brown R.C., Coprostanol distribution from sewage discharge into Sarasota Bay, Florida, Bull. Environ. Contam. Toxicol. 23 (1984) 75-79.
[17] Pocklington R., Leonard I.D., Crewe N.F., Le coprostanol comme indicateur de la contamination fécale dans l'eau de mer et les sédiments marins, Oceanol. Acta 10 (1) (1987) 83-89.

[18] Quéméneur M., Marty Y., Fatty acids and sterols in domestic waste waters, Water Res. 28 (5) (1994) 1217-1226.

[19] Saiz Salinas J.I., Francés Zubillaga G., Inlaz Ei zaguirre X., Uso de bioindicadores en la evaluación de la contaminación de la Ría de Bilbao,. Universidad del País Vasco, Leioa, 1996. $128 \mathrm{p}$.

[20] Sherwin M.R., Van Vleet E.S., Fossato V.U., Dolci F, Coprostanol (5B-cholestan-3B-ol) in lagoonal sediments and mussels of Venice, Italy, Mar. Pollut. Bull. 26 (9) (1993) 501-507.

[21] Shigenaka G., Price J.E., Correlation of coprostanol to organic contaminants in coastal and estuarine sediments of the U.S., Water Res. Bull. 24 (5) (1988) 989-998.

[22] Thornton S.F., McManus J., Application of organic carbon and nitrogen stable isotope and $\mathrm{C} / \mathrm{N}$ ratios as source indicators of organic matter provenance in estuarine systems: evidence from the Tay Estuary, Scotland, Estuar. Coast. Shelf S. 38 (1994) $219-233$.

[23] Venkatesan M.I., Kaplan I., Sedimentary coprostanol as an index of sewage addition in Santa Monica Basin, Southern Califomia, Environ. Sci. Technol. 24 (1990) 208-214.

[24] Vivian C.M.G., Tracing of sewage sludge in the marine environment: a review, Sci. Total Environ. 53 (1986) 5-40.

[25] Walker R.W., Wun C.K., Litsky W., Coprostanol as an indicator of fecal pollution, CRC Crit. Rev. Environ. Control 12 (2) (1982) 91-112.

[26] Writer J.H., Leenheer J.A., Barber L.B., Amy G.L., Chapara S.C., Sewage contamination in the Upper Mississippi River as measured by the fecal sterol, coprostanol, Water Res. 29 (1995) 1427-1436.

[27] Zar J.H., Biostatistical Analysis, 3rd ed., Prentice-Hall, New Jersey, 1996, 662 p. 